\author{
E. Kozuharova, I. Ionkova \& F. M. Raimondo
}

\title{
Invasive alien species: potential cheap resources of plant substances for medicinal use*
}

\begin{abstract}
Kozuharova, E., Ionkova, I. \& Raimondo, F. M.: Invasive alien species: potential cheap resources of plant substances for medicinal use. - Bocconea 28: 223-236. 2019. - ISSN: 1120-4060 printed, 2280-3882 online.

On the basis of the literature examined, the scientific acquisitions concerning the pharmacological properties and medicinal uses of Ambrosia artemisiifolia and Erigeron canadensis - two American vascular plants of Asteraceae family that have become invasive in Europe and others continents - are collected and discussed. The data reveal the potential of the invasive as cheap sources of compounds with valuable pharmacological activities. In addition to the two plants presented as a case study, there are hundreds of plant species at hand as potential assets to explore and make money.

Key words: Ambrosia artemisiifolia, Erigeron canadensis, Asteraceae, biologically active compounds, pharmacological activity, management, ecosystem services.
\end{abstract}

\section{Introduction}

Some alien plant species have high tolerance of various habitat conditions and elevated propagation ability. This promotes their aggressive invasive behaviour. Often they over compete the local vegetation. Additionally many of them suppress the seed germination and seedling development of local plants. In the newly invaded habitats they might not have suitable herbivores to control their populations (DAISIE 2009). The only effective enemy might be Homo sapiens. Humans are known with their destructive power once an object has become significant for industrial utilization. Due to the fact that these are aggressive invasive species, they can provide abundant and cheap resources of plant bioactive compounds which can be used for medicinal purposes. Additionally, excessive harvesting for medicinal use might contribute to decrease their populations and reduce the destructive impact of these species on natural habitats.

*Article first published online on 26 February 2019 in Flora Mediterranea 29: 13-25. 
The good practice in the traditional use of plants for remedial purposes is a precondition for successful phyto-therapeutic application. On these basis a modern scientific approach such as phytochemical and pharmacological investigations affirms the therapeutic effect.

Echinacea purpurea (L.) Moench. is an example of a plant with growing modern popularity based on good practices in Native Americans' traditional medicine (Austin 2004, Wilkes 2012).

The aim of this contribution is to review research data and reveal the potential of two invasive plants of Asteraceae family as cheap sources of compounds with valuable pharmacological activities.

\section{Material and metods}

On the basis of the literature examined, the scientific acquisitions concerning the pharmacological properties and uses of Ambrosia artemisiifolia L. and Erigeron canadensis L., two American species that have become invasive on different continents, are collected and discussed. Some brief botanical, distributive and ecological indications on these two species are given below.

Ambrosia artemisiifolia is an annual plant native to North America across Canada, the eastern and central United States, the Great Plains, and in Alaska; the Caribbean on Cuba, Hispaniola, and Jamaica; and South America in the southern bioregion (Argentina, Chile, Paraguay, Uruguay), the western bioregion (Bolivia, Peru), and Brazil. This species has been introduced in Europe at the end of 19th century in seed crops at various independent geographical points and at various times since its introduction in natural habitats. Recently, the number of naturalized populations increased considerably fast and it is considered to be the one of the most dangerous invasive alien species of Europe (Chauvel \& al. 2006; Kazinczi \& al 2008; Essl \& al. 2009; DAISIE 2009; Hodgins \& al. 2013).

Erigeron canadensis [= Conyza canadensis (L.) Cronquist] is an erect, annual plant. It is native throughout most of North America and Central America and invasive in Europe. It was introduced into Europe in the mid 17th century, likely along with Canadian furs shipped to France (Tilley 2012). This plant is associated with disturbed, open and unshaded habitats, such as cultivated land, abandoned fields, roadsides, ruderal places, and other open habitats. Canadian horseweed can reduce crop yields through direct competition for resources. (Tilley 2012). It also contains allelopathic chemicals which can inhibit germination and reduce seedling growth in several species (Shaukat \& al. 2003).

On the two plants chosen as a case study (Ambrosia artemisiifolia and Erigeron canadensis), here we present: 1) traditional ethnobotanical data from their native habitats; 2) modern investigations of pharmacological activity and essential secondary compounds.

\section{The case studies}

\section{Ambrosia artemisiifolia (Fig.1).}

This species contains phytotoxins and shows significant inhibitory effects on the seed germination and primary growth of crops (Ritter \& Coble 1981; Wang \& Zhu 1995; 


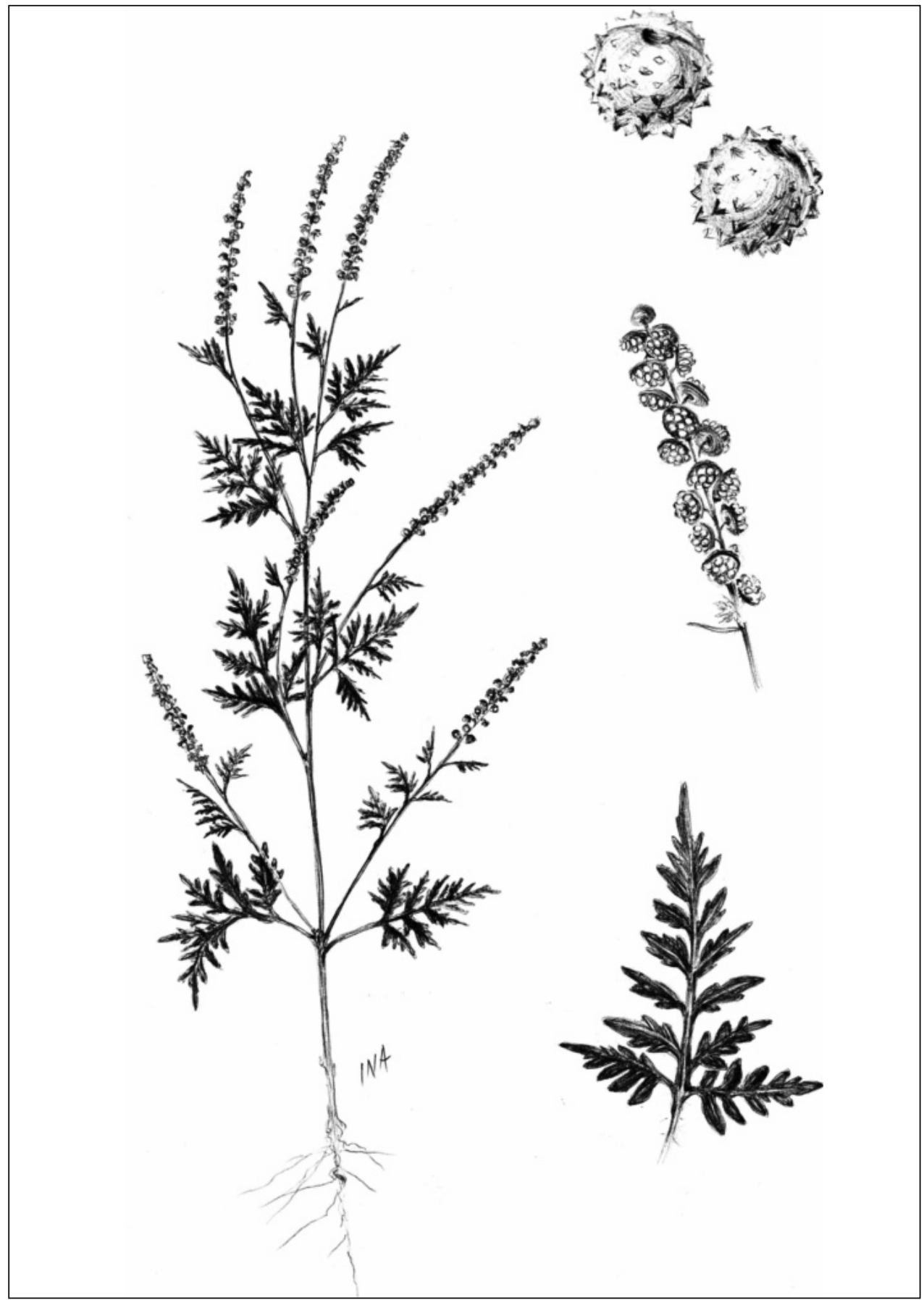

Fig. 1. Drawing of Ambrosia artemisiifolia from Bulgarian population (by E. Kozuharova). 
Brückner \& al. 2003; Vidotto \& al. 2013). High levels of naturally occurring variation in the ALS gene sequence have been found in A. artemisiifolia allowing rapid and widespread selection for resistance when ALS-inhibiting herbicides are used (Tranel \& al. 2004). The main problem is that its pollen is well known as noxious allergen (Mirone \& al. 2004; D’Amato \& al. 2007; Léonard \& al. 2010).

There are different therapeutic effects known to the Native Americans, which are well documented (Gilmore 1913; Speck 1941; Tantaquidgeon 1972; Hamel \& al. 1975; Herrick 1977; Shemluck 1982; Anderson \& al 1988; Austin 2004, Table 1).

Table 1. Ethnobotanical data and therapeutic effects of Ambrosia artemisiifolia known to the Native Americans.

\begin{tabular}{|l|l|l|l|}
\hline Tribe & Therapeuti effect & Method of application & References \\
\hline Cherokee & Dermatological Aid & $\begin{array}{l}\text { Crushed leaves rubbed on insect sting } \\
\text { and infusion of leaf rubbed on hives. }\end{array}$ & $\begin{array}{l}\text { Hamel \& al. 1975, } \\
\text { Moerman 1998 }\end{array}$ \\
\hline & Disinfectant & $\begin{array}{l}\text { Juice of wilted leaves applied to infected } \\
\text { toes. }\end{array}$ & $\begin{array}{l}\text { Hamel \& al. 1975 } \\
\text { Moerman 1998 }\end{array}$ \\
\hline & Febrifuge & Infusion of leaf taken for fever. & $\begin{array}{l}\text { Hamel \& al. 1975 } \\
\text { Moerman 1998 }\end{array}$ \\
\hline Dakota & Antidiarrheal & $\begin{array}{l}\text { Infusion of leaves and plant tops taken } \\
\text { for bloody flux. }\end{array}$ & $\begin{array}{l}\text { Hamel \& al. 1975 } \\
\text { Moerman 1998 }\end{array}$ \\
\hline & Antiemetic & $\begin{array}{l}\text { Infusion of leaves and plant tops taken } \\
\text { for vomiting. }\end{array}$ & $\begin{array}{l}\text { Gilmore 1913 } \\
\text { Moerman 1998 }\end{array}$ \\
\hline Delaware & Blood Medicine & $\begin{array}{l}\text { Poultice of plant used to prevent blood } \\
\text { poisoning. }\end{array}$ & $\begin{array}{l}\text { Tantaquidgeon } \\
\text { 1972, Moerman } \\
1998\end{array}$ \\
\hline Houma & Gynecological Aid & $\begin{array}{l}\text { Decoction of root taken for menstrual } \\
\text { troubles. }\end{array}$ & $\begin{array}{l}\text { Speck 1941, } \\
\text { Moerman 1998 }\end{array}$ \\
\hline Iroquois & Antidiarrheal & $\begin{array}{l}\text { Compound decoction of plants taken for } \\
\text { diarrhea with bleeding. }\end{array}$ & $\begin{array}{l}\text { Herrick 1977, } \\
\text { Moerman 1998 }\end{array}$ \\
\hline Luiseno & Emetic & Infusion of roots taken for stroke. & $\begin{array}{l}\text { Herrick 1977, } \\
\text { Moerman 1998 }\end{array}$ \\
\hline Mahuna & Dermatological Aid & $\begin{array}{l}\text { Infusion of plant used as a wash for } \\
\text { minor skin eruptions and scalp diseases. }\end{array}$ & $\begin{array}{l}\text { Romero1954, } \\
\text { Moerman 1998 }\end{array}$ \\
\hline Oto & Antiemetic & $\begin{array}{l}\text { Bruised leaves laid on scarified abdomen } \\
\text { for nausea. }\end{array}$ & $\begin{array}{l}\text { Gilmore 1919, } \\
\text { Moerman 1998 }\end{array}$ \\
\hline Lakota & $\begin{array}{l}\text { Antirheumatic } \\
\text { External) }\end{array}$ & $\begin{array}{l}\text { Decoction of plants taken for cramps } \\
\text { from picking berries. }\end{array}$ & $\begin{array}{l}\text { Herrick 1977, } \\
\text { Moerman 1998 }\end{array}$ \\
\hline & & Plant used for toilet paper. & $\begin{array}{l}\text { Rogers 1980, } \\
\text { Moerman 1998 }\end{array}$ \\
\hline & & $\begin{array}{l}\text { Rogers 1980, } \\
\text { Austin 2004, } \\
\text { Moerman 1998 }\end{array}$ \\
\hline
\end{tabular}


It contains sesquiterpenoids-sesquiterpene lactones, etc. (Bianchi \& al. 1968; David \& al. 1999; Sturgeon \& al. 2005; Taglialatela-Scafati \& al. 2012; Huang \& al. 2014; Ding \& al. 2015; Kiss \& al. 2017) as well as polyphenols and flavonoids (Parkhomenko \& al. 2005, 2006; Maksimovic 2008) or other constituents (Georgiev \& al. 2007).

Pharmacological tests revealed that Ambrosia artemisiifolia possess numerous activities such as cytotoxic, antimalarial, antimicrobial, anti-inflammatory, pronounced hepatoprotective and hypolipemic-lowers the concentration of fats in the blood (Table 2).

Principal constituents of the essential oil obtained by steam destilation are germacrene D (24.1\%), limonene (16.83\%), $\alpha$-pinene (8.0\%) and myrcene $(7.4 \%)$ with significant bactericidal and fungicidal activity (Chalchat $\&$ al. 2004, Table 2).

Table 2. Pharmacological activities of Ambrosia artemisiifolia.

\begin{tabular}{|l|l|}
\hline Activity of the plant extracts & Reference \\
\hline Antioxidant & Maksimovic 2008 \\
\hline Hypolipemic & Parkhomenko \& al. 2005, 2006 \\
\hline Hepatoprotective & Parkhomenko \& al. 2005, 2006 \\
\hline Cytotoxic & $\begin{array}{l}\text { Bianchi \& al. 1968; David \& al. 1999; } \\
\text { Sturgeon \& al. 2005; Huang \& al. 2014; } \\
\text { Kiss \& al. 2017 }\end{array}$ \\
\hline Antimalarial & David \& al. 1999 \\
\hline $\begin{array}{l}\text { Antimicrobial: antifungal, antibacterial, } \\
\text { antiviral }\end{array}$ & Georgiev 2007; Solujić \& al. 2008 \\
\hline Anti-inflammatory & Pérez 1996 \\
\hline Activity of the essential oil & Chalchat \& al. 2004 \\
\hline $\begin{array}{l}\text { Significant bactericidal and fungicidal } \\
\text { activity }\end{array}$ & \\
\hline
\end{tabular}

\section{Erigeron canadensis (Fig. 2).}

Ethnobotanical investigations reveal that there are number of therapeutic effects known to the Native Americans (Moerman 1998, 2009; Pennacio \& al. 2010; Austin 2010, Table 3 ). It is claimed that in folk medicine this plant is used in diarrhea, dysentery uterine hemorrhages, dropsy, gravel, cystitis, calculus, bronchial catarrh, and hemoptysis (Yan \& al. 2010, Shakirullah $\&$ al. 2011) but there is no indication for original native American tradition Phytochemical studies revealed that Erigeron canadensis contained saponins, diterpenoids, terpenoids, glycosides, tannin, anthraquinone, steroids and flavonoids (quercetin7-O-beta-D-galacto pyranoside, quercetin, luteolin, apigenin, 5,7,4'- trihydroxy-3'-methoxy flavone, quercetin-3-alpharhamnopyranoside, quercetin-3-O-beta-Dglucopyranoside, apigenin-7-O-beta-D-gluco pyranoside, luteolin-7-O-beta-D-glucuronide methyl ester,4'hydroxy baicalein-7-O-beta-Dglucopyranoside, baicalein and rutin). Also conyzolide; conyzoflavone; conyzapyranone A; conyzapyranone B; 4 Z,8 Z-matricaria- $\gamma$-lactone; 4 E,8 Z-matricaria- $\gamma$-lactone; 9,12,13-trihydroxy10(E)-octadecenoic acid; epifriedelanol; friedeline; taraxerol; simiarenol; spinasterol; stigmasterol; $\beta$ - sitosterol; $\mathrm{C} 10$ acetylenes; sesqui- 
Table 3. Ethnobotanical data and therapeutic effects of Erigeron canadensis known to the Native Americans.

\begin{tabular}{|l|l|l|l|}
\hline Tribe & $\begin{array}{l}\text { Method of } \\
\text { application }\end{array}$ & Therapeutic effect & References \\
\hline $\begin{array}{l}\text { Native } \\
\text { Americans }\end{array}$ & $\begin{array}{l}\text { smoke the flowers } \\
\text { and leaves }\end{array}$ & $\begin{array}{l}\text { for pleasure or to } \\
\text { relive head colds. }\end{array}$ & Pennacio \& al. 2010 \\
\hline $\begin{array}{l}\text { Native } \\
\text { Americans }\end{array}$ & gastointestinal aid & Moerman 2009 \\
\hline Chumash & $\begin{array}{l}\text { grind the plant } \\
\text { tea }\end{array}$ & $\begin{array}{l}\text { relive pain } \\
\text { kidney problems }\end{array}$ & Austin 2010 \\
\hline Navajo & crush leaves to & treat skin problems & Austin 2010 \\
\hline
\end{tabular}

Table 4. Pharmacological activities of Erigeron canadensis.

\begin{tabular}{|l|l|}
\hline Activity of the plant extracts & Reference \\
\hline $\begin{array}{l}\text { Antioxidant } \\
\text { (potent radical scavenging activity) }\end{array}$ & $\begin{array}{l}\text { Olas \& al. 2006; Saluk-Juszczak \& al. } \\
\text { 2010; Shah \& al. 2012; Park \& al. 2013 }\end{array}$ \\
\hline Anti-platelet and anticoagulant & $\begin{array}{l}\text { Olas \& al. 2006; Saluk-Juszczak \& al. } \\
\text { 2010; Pawlaczyk \& al. 2011 }\end{array}$ \\
\hline Antiinflammatory & Lenfeld \& al. 1986, Sung \& al. 2014 \\
\hline Antiproliferative & $\begin{array}{l}\text { Réthy 2007; Réthy \& al. 2007; Csupor- } \\
\text { Löffler \& al. 2009, 2011 }\end{array}$ \\
\hline Anti-gastric ulcer & Park \& al. 2013 \\
\hline De-pigmentation & Hong \& al. 2008 \\
\hline Antibacterial & Biswas \& Sinha 2014 \\
\hline Reduce blood glucose level in vitro & Aslam \& al. 2018 \\
\hline Activity of the essential oil & \\
\hline Anti-inflammatory & Guenter 1976 \\
\hline Haemostatic & Guenter 1976 \\
\hline Stimulant & Guenter 1976 \\
\hline Carminative & Guenter 1976 \\
\hline Antiproliferative & Choi 2008, \\
\hline Antifungal - evaluated to weak & Curini \& al. 2003 \\
\hline $\begin{array}{l}\text { Antifungal - evaluated to moderate or strong } \\
\text { activity against Candida, Cryptococcus, } \\
\text { Trichophyton, Rhodotorula but no } \\
\text { antibacterial activity }\end{array}$ & Veres \& al. 2012 \\
\hline Anti-melanoma B16 activity & \\
\hline
\end{tabular}




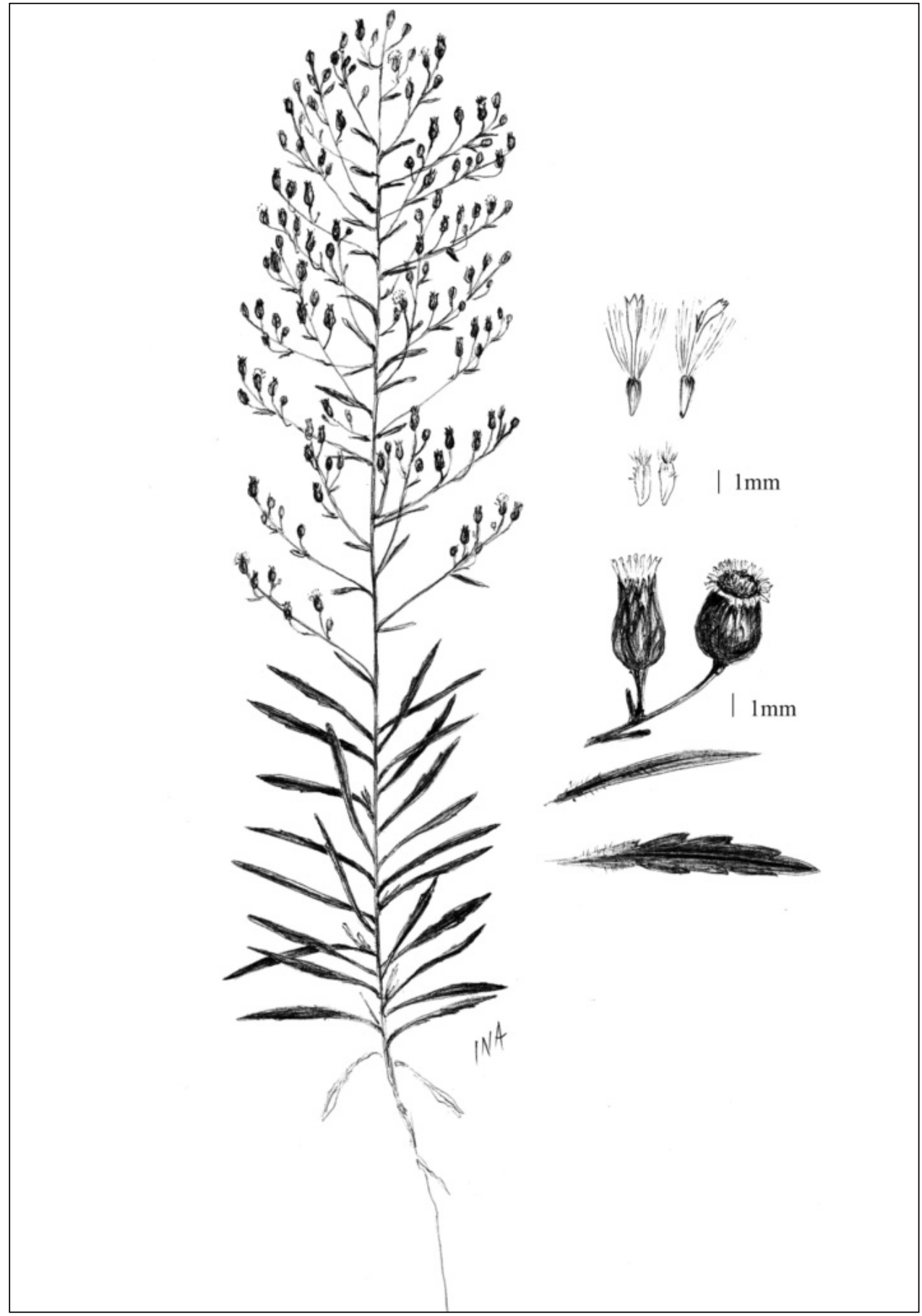

Fig. 2. Drawing of Erigeron canadensis from Bulgarian population (by E. Kozuharova). 
terpene hydrocarbons, beta-santalene, beta-himachalene, cuparene, alpha-curcumene, gamma-cadinene, sphingolipids 1,3,5-trihydroxy-2-hexadecanoyl amino-(6E,9E)-heptacosdiene; 1,3,5-trihydroxy-2- hexadecanoylamino-(6E,9E)-heptacosdiene-1Oglucopyranoside; 1,3-dihydroxy-2-hexanoylamino- (4E)-heptadecene; p-hydroxybenzoic acid, 3,5- dihydroxybenzoic acid, 3,5-dimethoxybenzoic acid; 3beta-hydroxyolean-12en-28-oic acid; 3beta-erythrodiol; beta-sitosterol; stigmasterol; beta-sitosterol 3-O-beta-Dglucoside and harmine were isolated from different parts of the plant (Bohlmann \& Jakupovic 1979; Lenfeld \& al. 1986; Czeczot \& al. 1990; Mukhtar \& al. 2002a, 2002b; Wei \& al. 2007; Shakirullah \& al. 2011; Csupor-Löffler \& al. 2011; Shao 2012; Shah \& al. 2012; Veres \& al. 2012; Biswas \& Sinha 2014).

Extracts of Erigeron canadensis were reported to have anti-inflammatory and anti-proliferative activity as well as gastric ulcer protective effect. Also anti-inflammatory, de-pigmentation, anti-coagulant, anti-platelet and anti-oxidant effects are reported (Table 4).

Health risks or side effects following the proper administration of designated therapeutic dosages were not recorded (Anonymous 2000).

The essential oil contains more than 30 constituents but is mainly composed of monoterpenoids-limomene, camphene, $\alpha$ and $\beta$-pinenes etc., and sesquiterpenoids - caryophyllene, germacrene D and $\alpha$-curcumene etc. (Miyazawa \& al. 1992; Lis \& Góra 2000; Rustaiyan \& al. 2004; Tzakou \& al. 2005; Lis \& al. 2005; Unnithan \& al. 2014, Ayaz \& al. 2017). A few non-terpenoid acetylenic compounds were also detected (Unnithan \& al. 2014). The compounds isolated from essential oils differ among different locations which may be attributed to the different environmental and climatic conditions (Unnithan \& al. 2014).

The essential oil of Erigeron canadensis possess anti-inflammatory, haemostatic, stimulant, carminative and antifungal activity (Table 4).

\section{Discussion and conclusion}

Ethnobotanical data from their habitats reveal promising medicinal potential. A growing body of scientific literature points to their therapeutic properties. Valuable chemical constituents of these alien invasive species are sesquiterpene lactones, essential oils etc. They posses different activities such as anticancer activity, as well as antitussive, antifungal, antiinflammatory, antinociceptive, hypoglycaemic, antimitotic, antioxidant, antitrypanosomal, CNS depressant activity, diuretic effects, contact dermatitis, insecticidal and herbicidal activities, hepatoprotective and hypolipemic activities etc.

Due to the fact that these are aggressive invasive species, they can provide abundant and cheap resources reach of plant chemical constituents which can be utilized for therapeutic purposes. Additionally, exploitation of the biomass for medicinal use might contribute to relieving the destructive impact of these species on natural habitats.

The invasive plant species considered in this contribution deserve further investigations as they have valuable pharmacological activities. Harvesting of the plants for their medicinal value may reduce the populations due to decreased seed production and propagation. This way additionally the risk of allergy caused by Ambrosia artemisiifolia pollen will decrease.

There are many studies conducted on the two species here examined and there is good reason to believe that there are prospects of study that can still provide other products that can 
contribute to give further value to negatively evaluated biological resources, since they are seen as harmful and competitive agents and not as a resource. Therefore, unexplored fields remain to which new research can be directed. In addition to the plants presented as a case study, there are hundreds of species at hand as potential assets to explore and make money.

\section{References}

Anderson, A. B., Zeidler, J. A., Dendy, J. H. \& Moerman, D. E. 1998: Assessing Installation Ethnobotanical Resources Using Land Condition Trend Analysis (LCTA) Data: A Fort Riley, Kansas, Case Study (No. CERL-TR-98-92). - Champaign.

Anonymous 2000. PDR for herbal medicines, 3 ed. - Montvale.

Aslam, H., Khan, A. U., Naureen, H., Ali, F., Ullah, F., \& Sadiq, A. 2018: Potential application of Conyza canadensis (L) Cronquist in the management of diabetes: In vitro and in vivo evaluation. - Trop. J. Pharm. Res. 17(7): 1287-1293. https://doi.org/10.4314/tjpr.v17i7.9

Austin, D. F. 2004: Florida ethnobotany. - Boca Raton.

- 2010: Baboquivari Mountain Plants: Identification, Ecology, and Ethnobotany. - Tuscon.

Ayaz, F., Küçükboyac1, N., \& Demirci, B. 2017: Chemical composition and antimicrobial activity of the essential oil of Conyza canadensis (L.) Cronquist from Turkey. J Essent Oil Res, 29(4): 336-343. https://doi.org/10.1080/10412905.2017.1279989

Bianchi, E., Culvenor, C. C. J. \& Loder, J. W. 1968: Psilostachyin, a cytotoxic constituent of Ambrosia artemsisiifolia L. - Australian J. Chem. 21(4): 1109-1111. https://doi.org/10.1155/2018/9185935

Biswas, K. \& Sinha, SN. 2014: Evaluation of antibacterial activity of Conyza canadensis (L.) Cronquist collected from Nainital, Uttarakhand, India. - Int. J. Univ. Pharm. Bio Sci. 3(1): 46-53.

Bohlmann, F. \& Jakupovic J. 1979: 8-Oxo- $\alpha$-selinen und neue scopoletin-derivate aus Conyza-arten. - Phytochemistry 18(8): 1367-1370. https://doi.org/10.1016/0031-9422(79)83024-1

Brückner, D. J., Lepossa, A. \& Herpai, Z. 2003: Inhibitory effect of ragweed (Ambrosia artemisiifolia L.)-inflorescence extract on the germination of Amaranthus hypochondriacus L. and growth of two soil algae. - Chemosphere 51(6): 515-519. https://doi.org/10.1016/S00456535(02)00790-7

Chalchat, J. C., Maksimovic, Z. A., Petrovic, S. D., Gorunovic, M. S., Dordevic, S. \& Mraovic, M. 2004: Chemical composition and antimicrobial activity of Ambrosia artemisiifolia L. essential oil. - J. Essential Oil Res. 16(3): 270-273.

Chauvel, B., Dessaint, F., Cardinal Legrand, C. \& Bretagnolle, F. 2006: The historical spread of Ambrosia artemisiifolia L. in France from herbarium records. - J. Biogeogr. 33(4): 665-673. https://doi.org/10.1111/j.1365-2699.2005.01401.x

Choi, H. J. 2008: Composition and cytotoxicity of essential oil extracted by steam distillation from horseweed (Erigeron canadensis L.) in Korea. - J. Korean Agric. Chem. Soc. 5(1): 55-59.

Curini, M., Bianchi, A., Epifano, F., Bruni, R., Torta, L. \& Zambonelli, A. 2003: Composition and in vitro antifungal activity of essential oils of Erigeron canadensis and Myrtus communis from France. - Chem. Nat. Compounds 39(2): 191-194. https://doi.org/0009-3130/03/3902-0191

Czeczot, H., Tudek, B., Kusztelak, J., Szymczyk, T., Dobrowolska, B., Glinkowska, G., Malinowski, J. \& Strzelecka H. 1990: Isolation and studies of the mutagenic activity in the Ames test of flavonoids naturally occurring in medical herbs. - Mutation Res. 240(3): 209-216. https://doi.org/10.1016/0165-1218(90)90060-F

Csupor-Löffler, B., Hajdú, Z., Réthy, B., Zupkó, I., Máthé, I., Rédei, T., Falkay, G. \& Hohmann J. 2009: Antiproliferative activity of Hungarian asteraceae species against human cancer cell lines. Part II. - Phytother. Res. 23(8): 1109-1115. https://doi.org/10.1002/ptr.2755 
—, —, Zupkó, I., Molnár, J., Forgo, P., Vasas, A., Kele, Z. \& Hohmann, J. 2011: Antiproliferative constituents of the roots of Conyza canadensis. - Pl. Med. 77(11): 1183-1188. https://doi.org/10.1055/s-0030-1270714

D’Amato, G., Cecchi, L., Bonini, S., Nunes, C., Annesi Maesano, I., Behrendt, H. \& Van Cauwenberge, P. 2007: Allergenic pollen and pollen allergy in Europe. - Allergy: 62(9): 976990. https://doi.org/10.1111/j.1398-9995.2007.01393.x

DAISIE, 2009: Handbook of Alien Species in Europe. - Dordrecht.

David, J. P., de O. Santos, A. J., da S. Guedes, M. L., David, J. M., Chai, H. B., Pezzuto, J. M. \& Cordell, G. A. 1999: Sesquiterpene lactones from Ambrosia artemisiaefolia (Asteraceae). Pharm. Biol. 37(2): 165-168. https://doi.org/10.1076/phbi.37.2.165.6077

Ding, W., Huang, R., Zhou, Z. \& Li, Y. 2015: New sesquiterpenoids from Ambrosia artemisiifolia L. - Molecules 20(3): 4450-4459. DOI:10.3390/molecules20034450

Essl, F., Dullinger, S. \& Kleinbauer, I. 2009: Changes in the spatio-temporal patterns and habitat preferences of Ambrosia artemisiifolia during its invasion of Austria. - Preslia 81(2): 119-133. https://doi.org/20103074756

Georgiev, M. I., Pavlov, A. I. \& Bley, T. 2007: Hairy root type plant in vitro systems as sources of bioactive substances. - Appli. Microbiol. Biotechnol. 74(6): 1175. https://doi.org/10.1007/s00253-007-0856-5

Gilmore, M. R. 1913: Some Native Nebraska Plants With Their Uses by the Dakota. - Coll. Nebraska State Hist. Soc. 17: 358-370.

— 1919: Uses of Plants by the Indians of the Missouri River Region. - SI-BAE Annual Report \#33. - Washington.

Guenter, E. 1976: Erigeron canadensis - Pp. 456-459 in: Guenter, E., The Essential Oils, 5. - Malabar.

Hamel, P. B. \& Chiltoskey, M. U. 1975: Cherokee Plants and Their Uses - A 400 Year History. - Sylva.

Herrick, J. W. 1977: Iroquois Medical Botany. - State University of New York, Albany, PhD Thesis.

Hodgins, K.A., Lai, Z., Nurkowski, K., Huang, J. \& Rieseberg, L. H. 2013: The molecular basis of invasiveness: differences in gene expression of native and introduced common ragweed (Ambrosia artemisiifolia) in stressful and benign environments. - Molec. Ecol. 22(9): 24962510. https://doi.org/10.1111/mec.12179

Hong, E. S., Nguyen, D. T. M, Nguyen, D. \& Kim, E. K. 2008: Inhibition of melanogenesis by Erigeron canadensis via down-regulating melanogenic enzymes in B16F10 melanoma cells. Korean J. Chem. Eng. 25(6): 1463-1466. https://doi.org/10.1007/s11814-008-0240-x

Huang, R., Ding, W., Zhou, Z. \& Li, Y. 2014: A novel eudesmane sesquiterpene glycoside from Ambrosia artemisiifolia L. - Biochem. Syst. Ecol. 57: 363-366. https://doi.org/10.1016/j.bse.2014.09.008

Kazinczi, G., Béres, I., Novák, R., Bíró, K. \& Pathy, Z. 2008: Common ragweed (Ambrosia artemisiifolia): a review with special regards to the results in Hungary. I. Taxonomy, origin and distribution, morphology, life cycle and reproduction strategy. - Herbologia 9(1): 55-91. https://doi.org/20093108558

Kiss, T., Szabó, A., Oszlánczi, G., Lukács, A., Tímár, Z., Tiszlavicz, L. \& Csupor, D. 2017: Repeated-dose toxicity of common ragweed on rats. - PloS ONE 12(5): e0176818. https://doi.org/10.1371/journal.pone.0176818

Lenfeld, J., Motl, O. \& Trka, A. 1986: Anti-inflammatory activity of extracts from Conyza canadensis. - Pharmazie 41(4): 268-269.

Léonard, R., Wopfner, N., Pabst, M., Stadlmann, J., Petersen, B. O., Duus, J. Ø. \& Ferreira, F. 2010 : A new allergen from ragweed (Ambrosia artemisiifolia) with homology to art $\mathrm{v} 1$ from mugwort. - J. Biol. Chem. 285(35): 27192-27200. https://doi.org/10.1074/jbc.M110.127118

Lis, A., \& Góra, J. 2000: Essential oil of Conyza canadensis (L.) Cronq. - J. Essential Oil Res. 12(6): 781-783. https://doi.org/10.1080/10412905.2000.9712214 
—, Piggott, J. R., \& Góra, J. 2003: Chemical composition variability of the essential oil of Conyza canadensis Cronq. - Flavour Fragrance J. 18(5): 364-367. https://doi.org/10.1002/ffj.1177

Maksimović, Z. 2008: In vitro antioxidant activity of ragweed (Ambrosia artemisiifolia L., Asteraceae) herb. - Industrial Crops Prod. 28(3): 356-360. https://doi.org/10.1016/j.indcrop.2008.04.001

Mirone, C., Albert, F., Tosi, A., Mocchetti, F., Mosca, S., Giorgino, M., Pecora, S., Parmiani, S., Ortolani, C. 2004. Efficacy and safety of subcutaneous immunotherapy with a biologically standardized extract of Ambrosia artemisiifolia pollen: a double-blind, placebo-controlled study. - Clin. Exp. Allergy 34(9): 1408-1414. https://doi.org/10.1111/j.13652222.2004.02056.x

Miyazawa, M., Yamamoto, K. \& Kameoka, H. 1992: The essential oil of Erigeron canadensis L. J. Essential Oil Res. 4(3): 227-230. https://doi.org/10.1080/10412905.1992.9698053

Moerman, D. E. 1998. Native American ethnobotany. - Portland.

- 2009: Native American medicinal plants: an ethnobotanical dictionary. - Portland.

Morazzoni, P., Cristoni, A., Di Pierro, F., Avanzini, C., Ravarino, D., Stornello, S., Musso, T. 2005: In vitro and in vivo immune stimulating effects of a new standardized Echinacea angustifolia root extract (Polinacea ${ }^{\mathrm{TM}}$ ). $\quad-\quad$ Fitoterapia 76(5): 401-411. https://doi.org/10.1016/j.fitote.2005.02.001

Mukhtar, N., Iqbal, K. \& Malik, A. 2002a: Novel sphingolipids from Conyza canadensis. - Chem. Pharm. Bull. 50(12): 1558-1560. https://doi.org/10.1248/cpb.50.1558

-, 一, Anis I. \& Malik, A. 2002b: Sphingolipids from Conyza canadensis. - Phytochemistry 61(8): 1005-1008. https://doi.org/10.1016/S0031-9422(02)00385-0

Olas, B., Saluk-Juszczak, J. \& Pawlaczyk I. 2006: Antioxidant and antiaggregatory effects of an extract from Conyza canadensis on blood platelets in vitro. - Platelets 17(6): 354-360. https://doi.org/10.1080/09537100600746805

Park, W. S., Bae, J. Y., Chun, M. S., Chung, H. J., Han, S. Y. \& Ahn, M. J. 2013: Suppression of gastric ulcer in mice by administration of Erigeron canadensis extract. - Proc. Nutrition Soc. 72: (OCE4), E263. https://doi.org/10.1017/S0029665113002887

Parkhomenko, A. Y., Andreeva, O. A., Oganesyan, E. T. \& Ivashev, M.N. 2005. Ambrosia artemisiifolia as a source of biologically active substances. - Pharm. Chem. J. 39(3): 149-153. https://doi.org/10.1007/s11094-005-0106-z

-, Oganesyan, E. T., Andreeva, O. A., Dorkina, E. G., Paukova, E. O. \& Agadzhanyan, Z. S. 2006: Pharmacologically active substances from Ambrosia artemisiifolia. Part 2. - Pharm. Chem. J. 40(11): 627-632. https://doi.org/10.1007/s11094-006-0208-2

Pawlaczyk, I., Czerchawski, L., Kuliczkowski, W., Karolko, B., Pilecki, W., Witkiewicz, W. \& Gancarz, R. 2011: Anticoagulant and anti-platelet activity of polyphenolic-polysaccharide preparation isolated from the medicinal plant Erigeron canadensis L. - Thrombosis Res. 127(4): 328-340. https://doi.org/10.1016/j.thromres.2010.11.031

Pennacio, M., Jefferson, L. \& Heavens, K. 2010: Uses and abuses of plant derived smoke. Its Ethnobotany as Hallucinogen, Perfume, Incense and Medicine. - Oxford.

Pérez, R. G. 1996: Anti-inflammatory activity of Ambrosia artemisiaefolia and Rhoeo spathacea. Phytomedicine 3(2): 163-167. https://doi.org/10.1016/S0944-7113(96)80030-4

Réthy, B. 2007: Antitumor effect of plant extracts and their constituents on cancer cell lines. $-\mathrm{PhD}$ thesis, Department of Pharmacodynamics and Biopharmacy, Faculty of Pharmacy, University of Szeged.

—, Csupor-Löffler, B., Zupkó, I., Hajdú, Z., Máthé, I. Hohmann, J., Rédei, T. \& Falkay, G. 2007: Antiproliferative activity of Hungarian asteraceae species against human cancer cell lines. Part I. - Phytother. Res. 21(12): 1200-1208. https://doi.org/10.1002/ptr.2240

Ritter, R. L. \& Coble, H. D. 1981: Penetration, translocation, and metabolism of acifluorfen in soybean (Glycine max), common ragweed (Ambrosia artemisiifolia), and common cocklebur 
(Xanthium pensylvanicum). $\quad-\quad$ Weed Sci. 29(4): 474-480. https://doi.org/10.1017/S0043174500040029

Rogers, D. J. 1980: Lakota Names and Traditional Uses of Native Plants by Sicangu (Brule) People in the Rosebud Area, South Dakota. - St. Francis.

Romero, J. B. 1954, The Botanical Lore of the California Indians. - New York.

Rustaiyan, A., Azar, P. A., Moradalizadeh, M., Masoudi, S. \& Ameri, N. 2004: Volatile constituents of three compositae herbs: Anthemis altissima L. var. altissima, Conyza canadensis (L.) Cronq. and Grantina aucheri Boiss. growing wild in Iran. - J. Essential Oil Res. 16(6): 579581. https://doi.org/10.1080/10412905.2004.9698802

Saluk-Juszczak, J., Olas, B., Nowak, P., Wachowicz, B., Bald, E., Głowacki, R., Pawlaczyk, I. \& Gancarz, R. 2010: Extract from Conyza canadensis as a modulator of plasma protein oxidation induced by peroxynitrite in vitro. - Cent. Eur. J. Biol. 5(6): 800-807. https://doi.org/10.2478/s11535-010-0065-6

Schoneberger, D. 1992: The influence of immune-stimulating effects of pressed juice from Echinacea purpurea on the course and severity of colds. - Forum Immunologie 8: 2-12.

Shah, N. Z., Muhammad, N., Azeem, S. \& Rauf, A. 2012: Studies on the chemical constituents and antioxidant profile of Conyza canadensis. - Middle-East J. Medic. Pl. Res. 1(2): 32-35.

Shakirullah, M., Ahmad, H., Shah, M. R., Ahmad, I., Ishaq, M., Khan, N., Badshah, A. \& Khan, I. 2011: Antimicrobial activities of conyzolide and conyzoflavone from Conyza canadensis. - J. Enzyme Inhibition Med. Chem. 26(4): 468-471. https://doi.org/10.3109/14756366.2010.528413

Shao, S, Yang, M. M., Bi, S. N. \& Wan, Z. Q. 2012: Flavonoids of Erigeron canadensis. - Zhongguo Zhong Yao Za Zhi 37(19): 2902-2905.

Shaukat, S. S., Munir, N. \& Siddiqui I. A. 2003: Allelopathic Responses of Conyza canadensis (L.) Cronquist: A Cosmopolitan Weed. - Asian J. Pl. Sci. 2(4): 1034-1039.

Shemluck, M. 1982: Medicinal and other uses of the Compositae by Indians in the United States and Canada. - J. Ethnopharmacol. 5(3): 303-358. https://doi.org/10.1016/0378-8741(82)90016-2

Solujić, S., Sukdolak, S., Vuković, N., Nićiforović, N. \& Stanić, S. 2008: Chemical composition and biological activity of the acetone extract of Ambrosia artemisiifolia L. pollen. - J. Serbian Chem. Soc. 73(11): 1039-1049. https://doi.org/10.2298/JSC0811039S

Sparkman, P. S. 1908: The Culture of the Luiseno Indians. - Amer. Archaeol. Ethnol. 8(4): 187-234.

Speck, F.G. 1941: A List of Plant Curatives Obtained From the Houma Indians of Louisiana. Primitive Man 14: 49-75.

Sturgeon, C. M., Craig, K., Brown, C., Rundle, N. T., Andersen, R. J. \& Roberge, M. 2005: Modulation of the G2 cell cycle checkpoint by sesquiterpene lactones psilostachyins A and C isolated from the common ragweed Ambrosia artemisiifolia. - Pl. Med. 71(10): 938-943. https://doi.org/10.1055/s-2005-873109

Sung, J., Sung, M., Kim, Y., Ham, H., Jeong, H.S. \& Lee, J. 2014: Anti-inflammatory effect of methanol extract from Erigeron canadensis L. may be involved with upregulation of heme oxygenase-1 expression and suppression of NF $\kappa$ B and MAPKs activation in macrophages. Nutr. Res. Pract. 8(4): 352-359. https://doi.org/10.4162/nrp.2014.8.4.352

Taglialatela-Scafati, O., Pollastro, F., Minassi, A., Chianese, G., De Petrocellis, L., Di Marzo, V. \& Appendino, G. 2012: Sesquiterpenoids from common ragweed (Ambrosia artemisiifolia L.), an invasive biological polluter. - Europ. J. Organic Chem. 2012(27): 5162-5170. https://doi.org/10.1002/ejoc.201200650

Tantaquidgeon, G. 1972: Folk Medicine of the Delaware and Related Algonkian Indians, Harrisburg. - Pennsylvania Hist. Commiss. Anthropol. Pap. 3: 1-35. 
Tilley, D. 2012. Plant Guide for Canadian horseweed (Conyza canadensis). USDA-Natural Resources Conservation Service, Aberdeen, ID Plant Materials Center. 83210-0296. https://plants.usda.gov/plantguide/pdf/pg_coca5.pdf [Last Accessed 01.01.2019]

Tranel, P. J. \& Wright, T. R. 2002: Resistance of weeds to ALS-inhibiting herbicides: what have we learned? - Weed Sci. 50: 700-712. https://doi.org/10.1614/0043-1745(2002)050[0700:RROW$\mathrm{TA}] 2.0 . \mathrm{CO} ; 2$

Tzakou, O., Vagias, C., Gani, A. \& Yannitsaros, A. 2005: Volatile constituents of essential oils isolated at different growth stages from three Conyza species growing in Greece. -Flavour Fragrance J. 20(4): 425-428. https://doi.org/10.1002/FFJ.1451

Veres, K., Csupor-Löffler, B., Lázár, A. \& Hohmann, J. 2012: Antifungal activity and composition of essential oils of Conyza canadensis herbs and roots. - Sci. World J. 2012: 489646. https://doi.org/10.1100/2012/489646

Vidotto, F., Tesio, F. \& Ferrero, A. 2013: Allelopathic effects of Ambrosia artemisiifolia L. in the invasive process. - Crop Protection 54: 161-167. https://doi.org/10.1016/j.cropro.2013.08.009

Wang, D. \& Zhu, X. 1995: Research on allelopathy of Ambrosia artemisiifolia. - Acta Ecol. Sinica 16(1): 11-19.

Wei, D. X., Gao, X. \& Zhong J. J. 2007: A new C-10 acetylene and a new triterpenoid from Conyza canadensis. - Arch. Pharm. Res. 30(5): 547-551. https://doi.org/10.1007/BF02977646

Wilkes, D. 2012: Herbal registrations rise rapidly in Europe. - OTC Bull. 23: 20-21.

Yan, M. M., Li, T. Y., Zhao, D. Q., Shao, S. \& Bi, S. N. 2010: A new derivative of triterpene with anti-melanoma B16 activity from Conyza canadensis. - Chinese Chem. Lett. 21(7): 834-837. https://doi.org/10.1016/j.cclet.2010.02.022

Addresses of the authors:

Ekaterina Kozuharova $^{1 *}$, Iliana Ionkova ${ }^{1} \&$ Francesco M. Raimondo $^{2}$,

${ }^{1}$ Medical University of Sofia, Department of Pharmacognosy, Faculty of Pharmacy, Bulgaria. E-mail: ina_kozuharova@yahoo.co.uk

${ }^{2}$ PLANTA/Mediterranean and Tropical Center for Research, Documentation and Training, Piazza Cairoli 11, 90123, Palermo, Italy.

*Corresponding author. 
